\title{
KRAS Exon 3 Mutation
}

National Cancer Institute

\section{Source}

National Cancer Institute. KRAS Exon 3 Mutation. NCI Thesaurus. Code C135716.

A molecular genetic abnormality indicating the presence of a mutation in exon 3 of the KRAS gene. 